\title{
Tactics and demographic attributes in the European eel Anguilla anguilla in the Gironde watershed, SW France
}

\author{
F. Daverat ${ }^{1, *}$, J. Tomás ${ }^{2}$ \\ ${ }^{1}$ Cemagref, 50 Avenue de Verdun, 33612 Cestas, France \\ ${ }^{2}$ IMEDEA, CSIC-UIB, Miquel Marquès 21, 07190 Esporles, Balearic Islands, Spain
}

\begin{abstract}
The patterns of habitat use and their relative proportions were investigated for 270 eels Anguilla anguilla sampled in coastal areas, the estuary and the river of the Gironde watershed, by measuring $\mathrm{Sr}$ and $\mathrm{Ca}$ concentrations in the otolith. Sr:Ca values outside the elver mark discriminated residence in the same habitat until capture (freshwater, estuary, or sea) from a switch of habitat following 3 patterns: a shift from freshwater to estuarine, seasonal movements within the limits of the estuary, or a switch of habitat from brackish to freshwater (downstream nomads). Results show a gradient of residency from freshwater (100\%) to estuary $(44 \%)$ to the sea $(24 \%)$. The most abundant $(30 \%)$ alternative to residence in an estuary and its adjacent coastal site were the downstream nomads, which concentrated in coastal areas and the lower part of the estuary after leaving freshwater. Overall, up to $50 \%$ of the eels analysed had spent a period in freshwater. Fish growth rates in freshwater were lower than anywhere else in the watershed. Back-calculation of fish sizeat-age showed that, of all eels passing through freshwater, residents were slow growers, while downstream nomads were fast growers. The latter migrate to the estuary at Ages 2+ and 3+, when their size is greater than estuarine residents. Results revealed that lower estuarine and marine habitats are colonised by yellow rather than glass eels. This suggests that competition with estuarine residents and downstream nomads prevents precocious settlement of glass eels in estuary and marine habitats.
\end{abstract}

KEY WORDS: Anguilla anguilla $\cdot$ Catadromy $\cdot$ Otolith $\cdot \mathrm{Sr}: \mathrm{Ca} \cdot$ Life-history pattern

\section{INTRODUCTION}

Diadromous fish populations display a high level of life-cycle plasticity, and their populations are often composed of fractions with different life histories. Partial migration, the phenomenon by which populations are composed of migratory and resident components, has been investigated for a large number of salmonid and other anadromous species (Jonsson \& Jonsson 1993). In the same manner, for catadromous species, the partition of population into ecophenotypes with alternative life strategies has been described mainly for temperate eels (Tsukamoto \& Arai 2001, Tzeng et al. 2002).
The European eel Anguilla anguilla is a catadromous fish that spawns in the Sargasso Sea. The larvae drift with the Gulf Stream and North Atlantic Current to the continental shelf of Europe and North Africa, where they metamorphose into glass eels (Tesch 2003). They become pigmented elvers as they penetrate estuaries, rivers and streams, and complete their growth phase in a large range of habitats (lagoons, estuaries, marshes, rivers, lakes and streams). The growth phase lasts from 3 to $15 \mathrm{yr}$ or more and is followed by a second metamorphosis into silver eel. Silver eels achieve sexual maturity as they swim back to their spawning grounds in the Sargasso Sea. 
Many studies based on otolith microchemistry have hypothesised that, among a single eel population, different life-history tactics coexist, related to the choice of habitat (marine, brackish, freshwater) or a shift of habitat (Tzeng et al. 2000a, 2002, 2003, Tsukamoto \& Arai 2001, Jessop et al. 2002, Limburg et al. 2003, Morrison et al. 2003, Arai et al. 2004, Daverat et al. 2005, Kotake et al. 2005). However, most studies are qualitative and only describe the occurrence of a certain tactic; they do not always evaluate the proportion of the river basin population involved.

The partitioning of divergent life histories is amazingly consistent for 5 species of temperate eels: Anguilla anguilla in the Baltic Sea (Tzeng et al. 2000b), A. rostrata (Jessop et al. 2002, Morrison et al. 2003), A. japonica (Tsukamoto \& Arai 2001, Tzeng et al. 2002) and the New Zealand eels A. diffenbachii and A. australis (Arai et al. 2004). This partitioning reflects the separation of populations into riverine-, estuarine- and marine-resident fractions and a group of eels often called 'migrants', 'transients', or 'nomads' (Tsukamoto \& Arai 2001, Daverat et al. 2005) that move from one compartment to another once or more during their growth phase.

A higher growth rate in a more productive environment is probably the main advantage of estuarine and coastal residence (Morrison \& Secor 2003). On the other hand, freshwater residency results in a lower mortality rate compared to marine environments (Jonsson \& Jonsson 1993). It is probable that the choice of a tactic would result in a specific demographic attribute (size-at-age, size-at-migration). However, comparison of the growth rates of migratory contingents are contradictory. Morrison et al. (2003) showed that Anguilla rostrata estuarine residents and 'freshwater to estuary mode' nomads have similar growth rates, which are higher than those of freshwater residents, whereas Tzeng et al. (2002) only found significantly different growth rates between similar ecophenotypes of $A$. japonica for the first $5 \mathrm{yr}$ of life, using retrospective growth analysis. A recent study by Kotake et al. (2005) pointed out that eels, which were collected in a Japanese bay, with different types of habitat use (estuarine, marine and freshwater eels) emigrate as female silver eels at the same size.

The adoption of a tactic of habitat use may be influenced by environmental conditions, as well as by the individual's status. Results obtained for salmonids emphasise the influence of the individual status, often associated with size at a given age (Thieriault \& Dodson 2003). For eels moving from one compartment to another, fast growth, or larger size-at-age may favour migration. A recent finding on thyroid status related to migratory behaviour of glass eels (Edeline et al. 2004) suggested that physiological stress leads to precocious settlement of eels in the estuary.
The first objective of this study was to describe the diversity of life histories of the European eels Anguilla anguilla encountered in the Gironde watershed and to calculate their relative proportions in the compartments of the river basin (coastal compartment, estuarine compartment and river compartment) using otolith microchemistry. The second objective was to evaluate the differences in demographic attributes (age, sex, size, growth rate) between life-history types. Finally, we investigated the mechanisms of segregation of patterns of habitat use by comparing the back-calculated size-at-age for the different groups.

\section{MATERIALS AND METHODS}

Study site. Coastal sites: The Arcachon Bay is a large bay (Fig. 1), with a wide opening to the Atlantic Ocean, characterised by eel grass Zostera marina and Z. nana meadows, where the salinity ranges between 25 and 35 psu. The Pertuis (Fig. 1) constitutes a large shallow coastal zone, that receives the influence of Gironde estuary panache as well as the runoff of other smaller rivers. Islands (the main ones being Oleron and Re), which provide shelter for eels, support an intensive oyster culture. The salinity in this zone varies between 20 and 35 psu.



Fig. 1. Map of the study site showing the Gironde-GaronneDordogne watershed, the Pertuis coastal area and the Bay of Arcachon 
Estuarine sites: The Gironde estuary (Fig. 1), the largest European estuary, is $76 \mathrm{~km}$ long. It varies in width from 2 to $11 \mathrm{~km}$ at its widest part. Its surface area is approximately $625 \mathrm{~km}^{2}$ at high tide. The bottom of the estuary is mainly a mixture of sand and mud, with the sandiest part in the lower sectors and the muddiest part in the upper sectors (Castaing 1981, Sottolichio 1999). In the Gironde estuary, the salinity gradient varies upstream between 33 and 0 psu and changes with tide and season (Castaing 1981, Sottolichio 1999). The limit of the estuary is defined with the 0 psu salinity front.

Riverine sites: Fish were sampled in the Garonne and Dordogne Rivers, both in the tidally influenced part of the river (also called the tidal freshwater estuary) and in the river without tidal influence downstream of the first dams.

Field sampling. A total of 270 eels were collected in the different salinity zones of the study site during every season of 2001, 2002, 2003 and 2004. Two types of fishing gear were used in this study: eels from the river $(n=63)$ and Arcachon Bay $(n=20)$ were fished with commercial type fyke nets, whereas the eels from the Gironde estuary $(n=162)$ and the Pertuis $(n=25)$ were collected in every season with both a small meshed benthic trawl and fyke nets, in order to cover most of the habitats of the river basin. The eels were sacrificed in clove oil. Total length $(\mathrm{mm})$ and weight $(0.01 \mathrm{~g})$ were recorded. Sex was determined according to macroscopic examination of the gonad. The eels collected in the present study were manipulated and sacrificed according to ethics legislation and to minimise suffering (Anonymous 1998).

Estimation of eel maturity. A new method using external measures of morphometry (Durif et al. 2005) was used to estimate the maturity of the eels, based on measures of fish weight, total length, pectoral fin length and eye diameter. These external measures were found to vary with hormone levels and gonadosomatic index as fish maturation progressed. In this system of classification, maturation is described by 5 levels from Stage I (yellow eels) to Stage V (silver eels).

Chemical analyses of the otolith. Sagittal otoliths were extracted, rinsed 3 times with Milli-Q water, dried and stored until they were embedded in epoxy resin. Otoliths were ground in the sagittal plane to expose the core (Fig. 2), polished using $1 \mu \mathrm{m}$ diamond paste and coated with a $3 \mathrm{~nm}$ layer of gold. A Cameca SX 100 Wavelength Dispersive X-ray Spectrometry (WDS) instrument was used to analyse $\mathrm{Sr}$ and $\mathrm{Ca}$ in otoliths. Andradite and $\mathrm{SrFCl}$ were used as standards. A nominal beam diameter of $8 \mu \mathrm{m}$ was used in raster mode, with an accelerating voltage of $15 \mathrm{keV}$ and a current of $10 \mathrm{nA}$. Sr and Ca counting times at their peaks were 100 and $30 \mathrm{~s}$, respectively (Daverat et al. 2004). Transects of probe points were performed from the primordium to the edge of the otolith along the postrostral axis (Fig. 2).

Age reading. After WDS analyses, otoliths were repolished to remove the coating, etched with $10 \%$

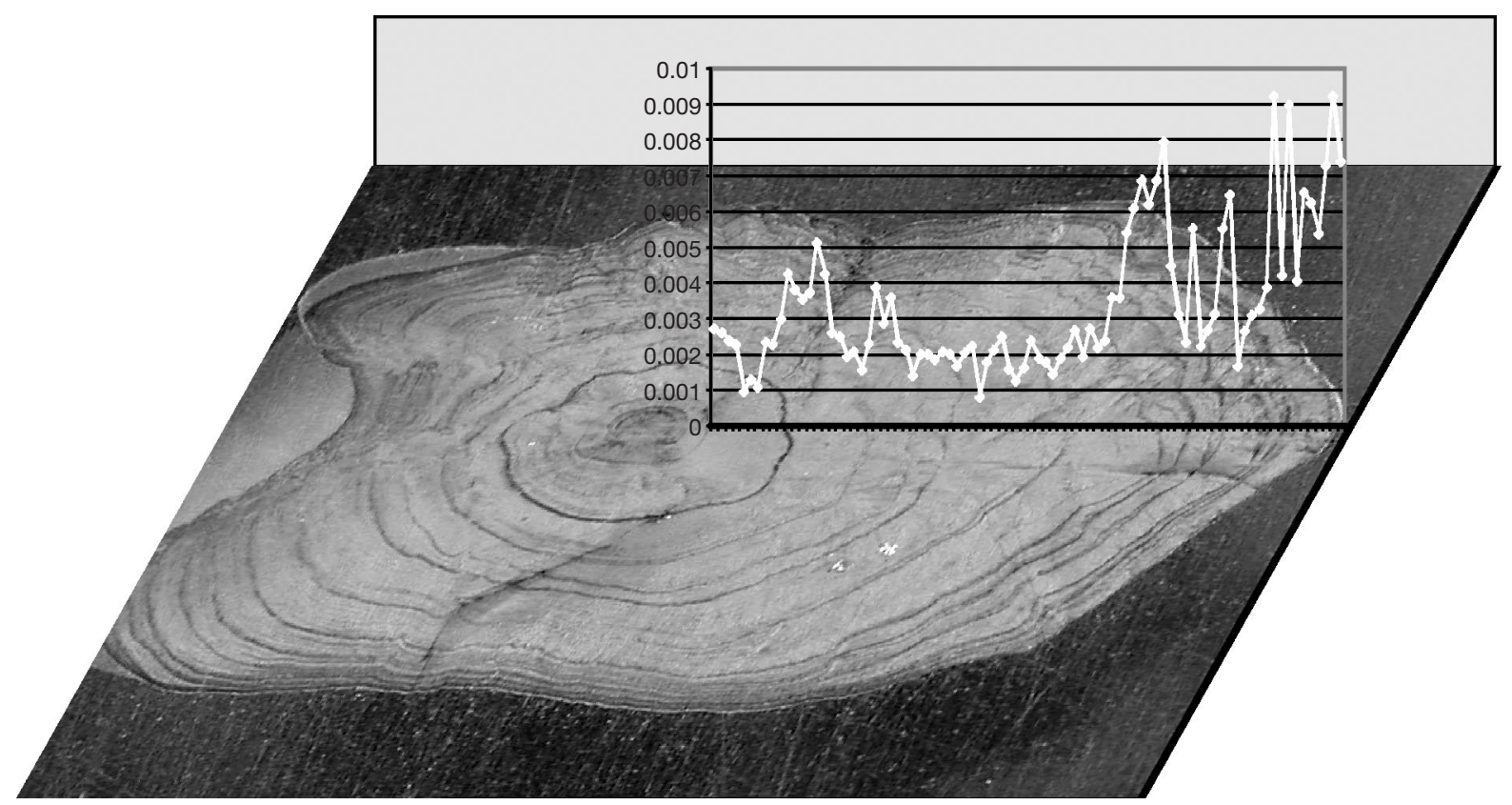

Fig. 2. Anguilla anguilla. Sr:Ca profile of variation along the growth axis of an otolith 
EDTA and then stained with $5 \%$ toluidine blue to enhance the annuli (Fig. 2). The number of annuli was read 3 times from the same picture. For each otolith, the distance between the primordium and the postrostrum was measured. Along this axis, which matched the WDS transect, the size of each annuli was recorded for back-calculation purposes.

Data analysis. Classification of life histories: Both data from a previous validation (Daverat et al. 2005) and the total distribution of all $\mathrm{Sr}: \mathrm{Ca}$ values measured outside the glass eel mark were used to assign a location (a saline compartment: sea, estuary, river) to each single value in each individual otolith $\mathrm{Sr}$ :Ca profile. A decision tree was built in order to classify each $\mathrm{Sr}$ :Ca transect of values outside the glass eel mark. The temporal dimension of the $\mathrm{Sr}$ :Ca series was given by the position of the age marks on each profile. Individual cases representative of a pattern of habitat use are presented in Fig. 3. The Sr:Ca reference values for a freshwater eel resident for the Gironde watershed was $<0.002$, the marine water value of $\mathrm{Sr}$ :Ca in the otolith being $>0.006$. The Sr:Ca otolith values for the Gironde estuary ranged between 0.002 and 0.005 , according to the geographical gradient (which matched the salinity gradient). The frequencies of the whole-otolith $\mathrm{Sr}: \mathrm{Ca}$ values were distributed, in accordance with the valida-
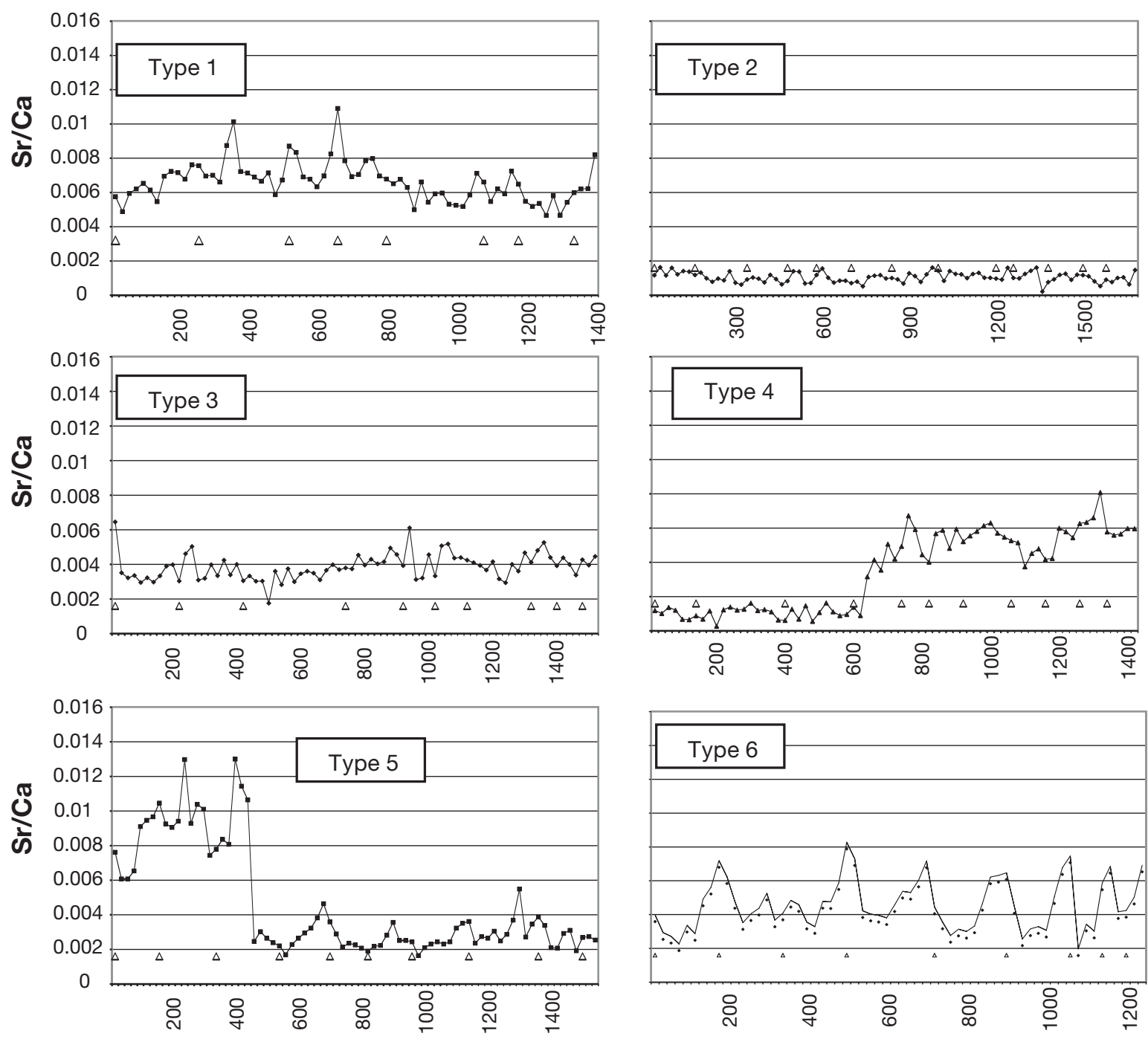

Distance from glass eel mark (microns)

Fig. 3. Anguilla anguilla. Sr:Ca variations along line transects from the first annulus to the otolith edge of 6 eels collected in the Gironde watershed (coast, estuary and river), with different life-history types. Triangles marks above the $x$-axis represent the position of age annuli. Type 1: marine resident (residence in coastal compartment); Type 2: riverine resident (residence in freshwater); Type 3: estuarine resident (residence in the estuary); Type 4: downstream nomad (residence in freshwater, movement to the estuary); Type 5: upstream nomad (residence in marine compartment, movement to the estuary); Type 6: seasonal nomad (seasonal movements between the lower and upper part of the estuary) 
tion data, following 3 Gaussian curves (river, estuary, sea). The probability distributions of the Gaussian curves were used to assign a location to each value of each otolith profile. Each individual time series of assigned locations was then interpreted as a sequential occupation of habitat. In consequence, outside the glass eel mark, fish that did not change compartment until capture belonged to the marine resident group (Type 1), the freshwater group (Type 2), or the estuarine resident group (Type 3 ) according to the Sr:Ca values (Fig. 3). Individuals that presented a sequence with a radical change of habitat were classified into the 'nomad' group with either 'downstream movement' group (Type 4, from river to estuary) or 'upstream movement' (Type 5, from the sea to the estuary), depending on the trend in the values (Fig. 3). Finally, individuals that presented periodic variations of locations in phase with age marks were classified in the 'seasonal movement' group (Type 6), and were interpreted to be eels that undertook seasonal movements between the upper part and the lower part of the estuary (Fig. 3). This seasonal pattern was a general movement observed for other species in the Gironde estuary as well (Lobry \& Rochard 2003).

Age data: Age was computed as a continuous variable: a theoretical birth date of 1 March was applied as this date coincided with the end of the peak of glass eel migration in the Gironde estuary. Only continental age (i.e. time after the glass eel stage) was considered here, so that age was then a function of the date of capture and the number of rings after the glass eel mark. For fishes captured from March to January, the number of days between 1 March and the date of capture were added to the number of rings as a fraction of year. For fish captured from 30 January to 28 February, the number of days between 1 March of the previous year and the date of capture was added to the number of rings.

Growth data: The growth rate of the fish was computed as a relationship between fish length and age from the glass eel stage, such that:

$$
G_{\mathrm{f}}=\frac{L_{\mathrm{C}}-L_{\text {glass eel }}}{t}
$$

where $G_{\mathrm{f}}$ is the fish growth rate, $L_{\mathrm{c}}$ is the fish length at capture, $L_{\text {glass eel }}$ is the mean glass eel length (value of $73 \mathrm{~mm}$ for the Gironde estuary) and $t$ is the continental age estimated by counting the rings after the glass eel mark.

A generalised linear model (GLM) (McCullagh \& Nelder 1989) was applied to the data with a post-hoc test (Tukey) in order to estimate the effect of type of habitat use on the growth rate. A level of alpha = 0.05 was selected prior to conducting statistical testing.
Back-calculation model: Lengths-at-age back-calculated from otolith data have been broadly used in eel (Anguilla spp.) ecology and found to be consistent with direct observations of lengths-at-age (Panfili et al. 1994, Graynoth 1999). The Whitney and Carlander model (Francis 1990) was applied to the relationship between fish length and otolith radius. This model assumes a constant proportionality between fish growth and otolith growth throughout the life of the fish. Hence, a regression of fish length against otolith length was used (Francis 1990). The relationship between fish length and otolith length was assumed to be linear, such that:

$$
L_{\mathrm{C}}=a+b \times R_{\mathrm{C}}
$$

with a body-proportional hypothesis, the back-calculation formula would then be:

$$
L_{t}=\left(\frac{a+b \times R_{t}}{a+b \times R_{\mathrm{c}}}\right) \times L_{\mathrm{c}}
$$

where $L_{\mathrm{C}}$ is the length of fish at capture, $R_{\mathrm{C}}$ is the otolith radius at capture, $L_{t}$ is the length of fish at age $t, R_{t}$ is the radius of the otolith at age $t$ and $a, b$ are constants.

The data was processed with a GLM that allowed us to fit the regression of fish length on otolith length for each type of habitat use and to test for significant differences between patterns of habitat use. Fish size to otolith size relationships were calculated for each group, and were further applied to back-calculate sizeat-age for each group.

\section{RESULTS}

\section{Size-frequency distributions and sex}

The estuarine sample contains the largest range of sizes, with total length ranging from 165 to $855 \mathrm{~mm}$ (Fig. 4). The lengths of eels collected in the river range from 225 to $615 \mathrm{~mm}$, while the lengths of the coastal sample range from 285 to $735 \mathrm{~mm}$ (Fig. 4). The overall sample is composed of $4 \%$ male eels, $28 \%$ undifferentiated eels and $68 \%$ female eels. There is great variation in the distribution of sex ratios between the types of habitat use (Table 1). The greatest proportion of males $(12 \%)$ was found among the marine residents, while the 'upstream movement' and 'seasonal movement' nomads and the river residents had the lowest proportion of males $(0$ to $1 \%)$. Discarding the 'upstream movement' nomads from the analysis, because of small sample size, the nomads had a greater proportion of females (86 and 95\%) than did the residents (up to $73 \%$ ), as shown in Table 1, and they tended to have a lower proportion of undifferenti- 

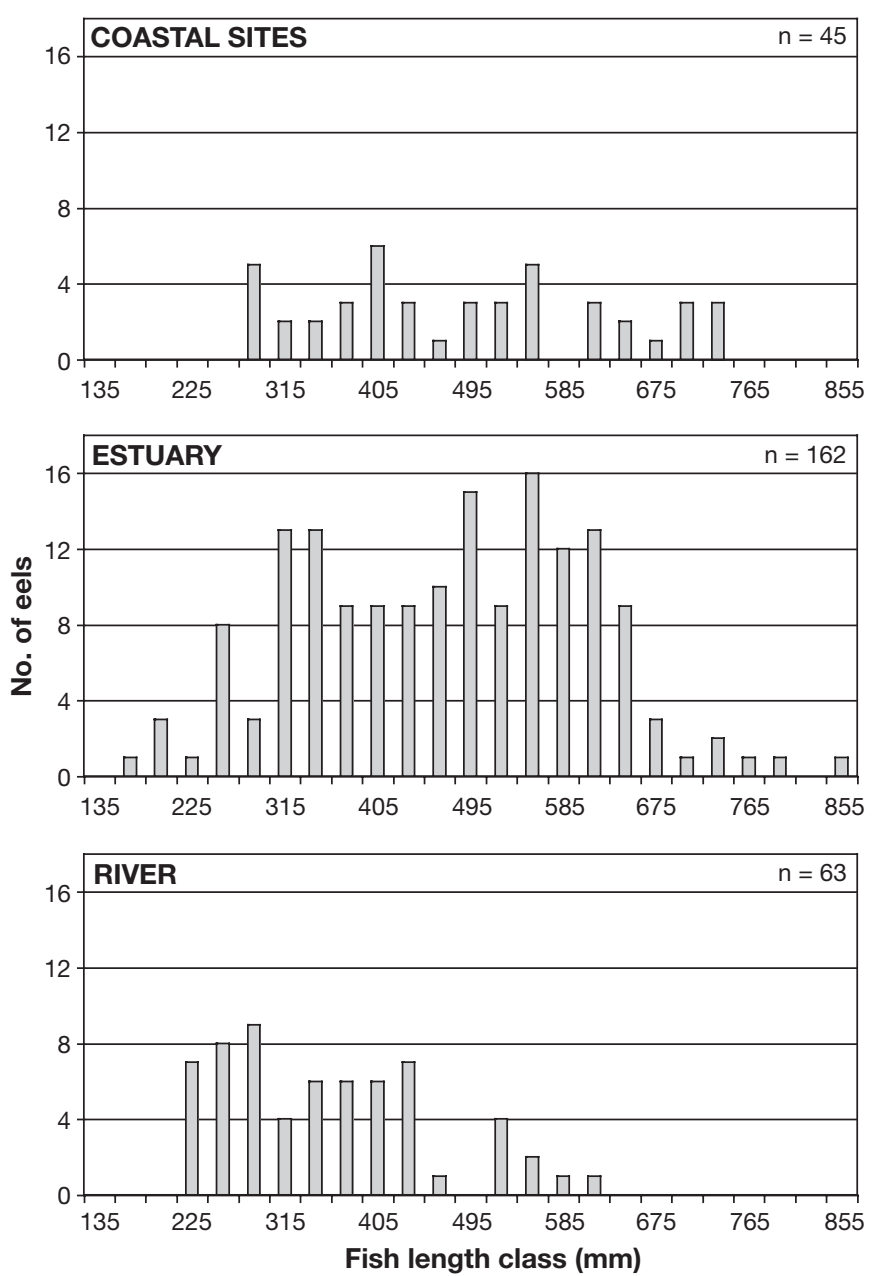

Fig. 4. Anguilla anguilla. Frequency distribution of total length of eels for each compartment

ated eels. In the overall sample, 27 female eels and only 1 male were found among Stage V eels (silver eels). Among the silver female eels, 9 and 14 were estuarine residents and nomads, respectively, while 2 were river residents and 2 others were marine residents. The silver eel mean length for female estuarine residents $( \pm$ SD: $597 \pm 66 \mathrm{~mm})$ was not significantly different from that of 'downstream movement', 'upstream', or 'seasonal' nomads ( $573 \pm 49 \mathrm{~mm})$, as shown by $t$-test $(\mathrm{p}=0.19)$.

Table 1. Anguilla anguilla. Distribution of sex ratios (\%) for each type of habitatuse pattern

\begin{tabular}{|lccccrr|}
\hline Sex & $\begin{array}{c}\text { Marine } \\
\text { resident }\end{array}$ & $\begin{array}{c}\text { Riverine } \\
\text { resident }\end{array}$ & $\begin{array}{c}\text { Estuarine } \\
\text { resident }\end{array}$ & $\begin{array}{c}\text { Downstream } \\
\text { nomad }\end{array}$ & $\begin{array}{c}\text { Upstream } \\
\text { nomad }\end{array}$ & $\begin{array}{c}\text { Seasonal } \\
\text { nomad }\end{array}$ \\
\hline Male & 12 & 1 & 5 & 6 & 0 & 0 \\
Female & 73 & 40 & 72 & 86 & 100 & 95 \\
Undifferentiated & 15 & 59 & 23 & 8 & 0 & 5 \\
Total number & 26 & 83 & 80 & 51 & 7 & 21 \\
\hline
\end{tabular}

\section{Proportions of patterns of habitat use}

River compartment

Collectively, the overall sample of eels analysed in this study displayed a wide repertoire of habitat-use patterns, as shown in Fig. 5. Of the 63 eels collected in the freshwater river compartment, only 2 individuals had $\mathrm{Sr}: \mathrm{Ca}$ values consistent with an estuarine residence, while the rest of the sample was composed of eels that remained in freshwater from the elver stage until capture (Fig. 5), called 'riverine residents'. Moreover, the 2 estuarine eels had been collected in the river close to the zone of estuarine influence (Fig. 5).

\section{Estuary}

The eels collected in the estuary displayed a large diversity of life-history patterns: $44 \%$ of eels were estuarine residents, $15 \%$ were freshwater residents and $41 \%$ were nomads (Fig. 5). The majority ( $27 \%$ ) of the nomads exhibited a downstream mode, whereas $12 \%$ of the total sample was composed of eels with seasonal movements, and a marginal number $(2 \%)$ were eels moving upstream, from the coastal compartment towards the upper part of the estuary (Fig. 5). Segmentation of the estuary into 3 compartments according to the salinity regime (Fig. 5) showed that the majority of riverine residents caught in the estuary were found in the compartment closer to the river. The proportion of estuarine resident eels decreased towards the coast, while the proportion of nomads that first settled in freshwater then moved to the estuary ('downstream nomads') increased.

\section{Coastal compartment}

Of the eels collected in the coastal compartment, $57 \%$ were classified as marine residents (Fig. 5), 16\% were estuarine residents and $16 \%$ were nomads, with a majority of downstream nomads. Analysis according to the site of capture revealed very contrasting results: all Arcachon eels were marine residents, but in the Pertuis coastal area only $24 \%$ fell into this catagory. A notable proportion of estuarine eels ( $28 \%$ ) was collected in the Pertuis area. Moreover, $48 \%$ of the eels in the Pertuis sample were nomad eels, mainly eels that moved from freshwater to the coastal zone (Fig. 5).

Overall results show a trend of decreasing residency from the river 

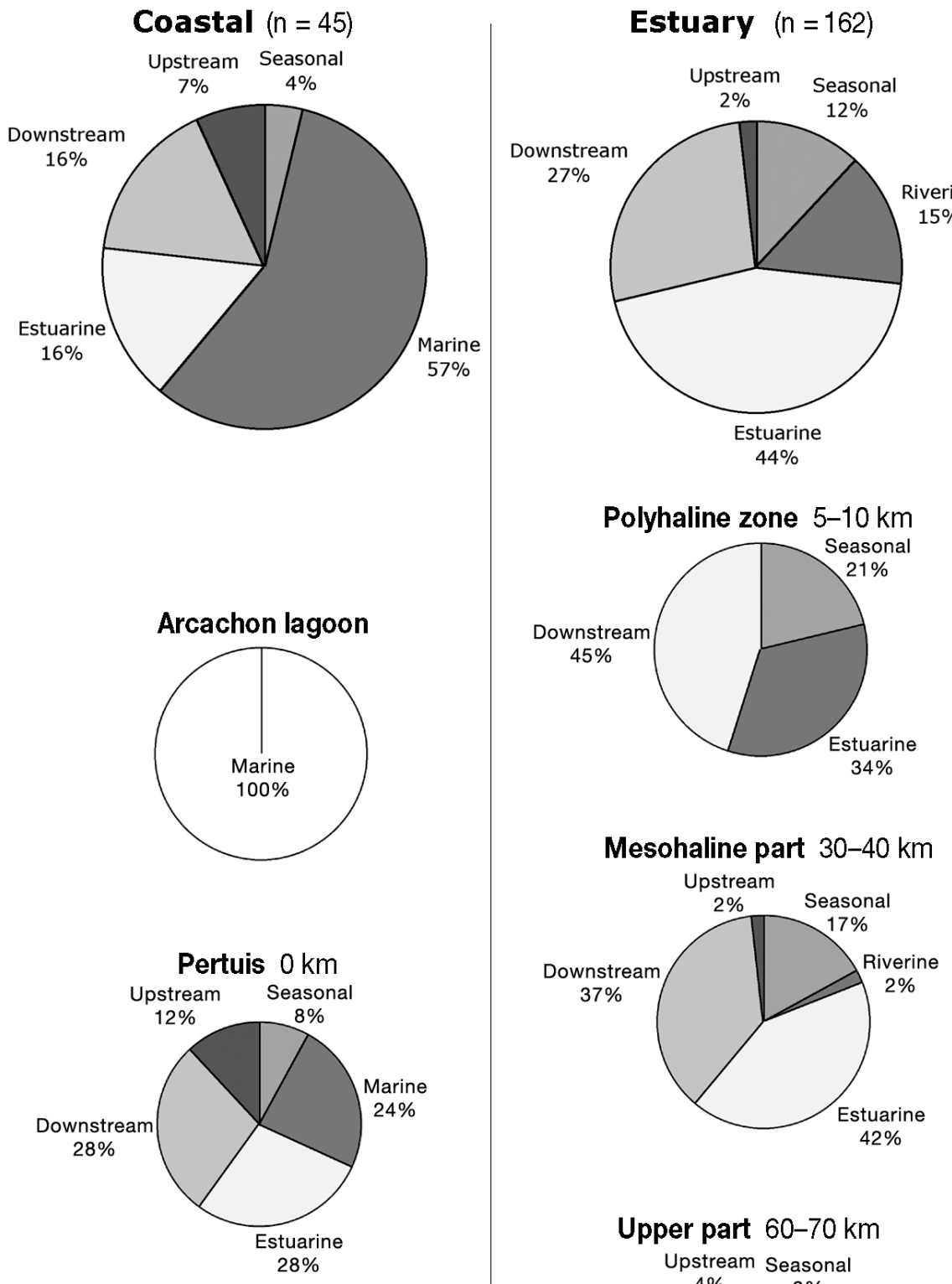

5. Anguilla anguilla. Proportions of habitat-use patterns in the
specified in $\mathrm{km}$
$44 \%$



River with tidal influence $70-90 \mathrm{~km}$
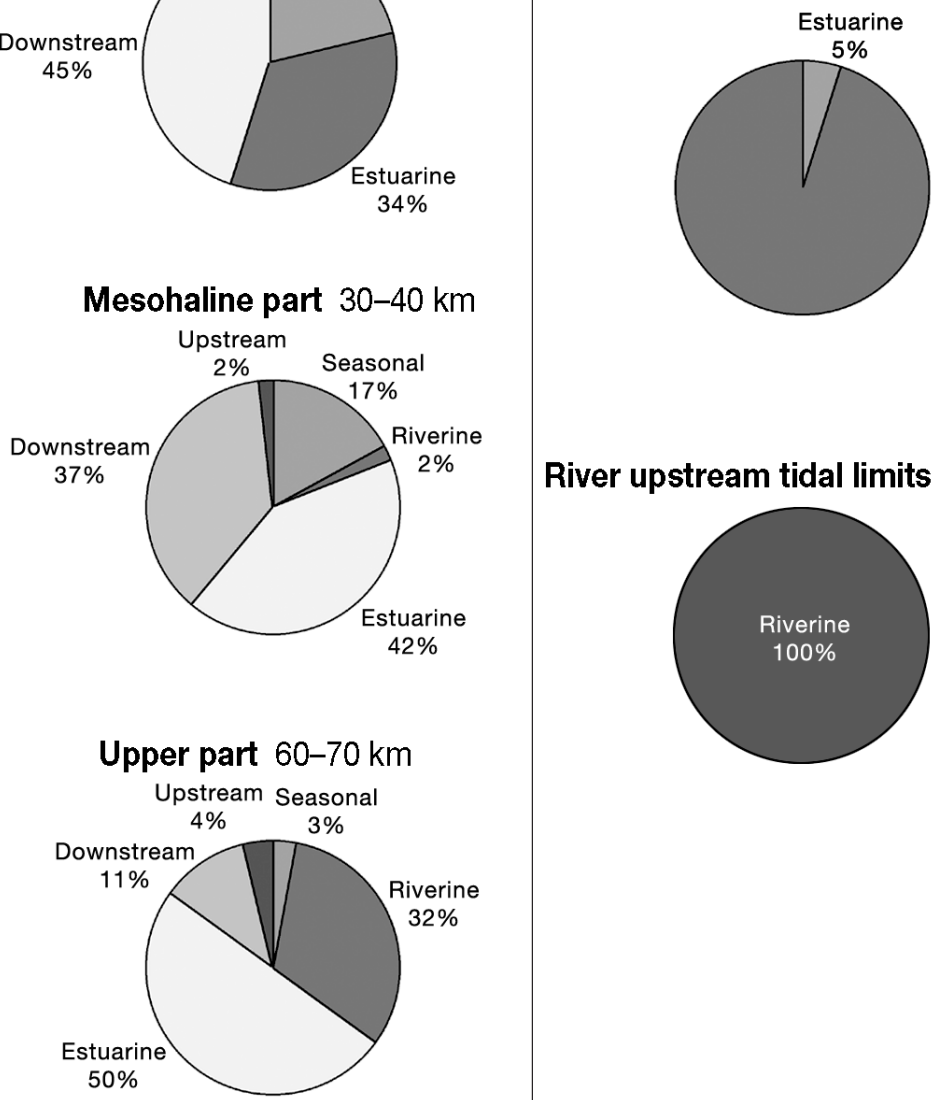

River upstream tidal limits $200 \mathrm{~km}$



towards the coastal areas. The proportion of resident fish decreased from $100 \%$ in the rivers to $95 \%$ in the river with tidal influence, $50 \%$ in the upper part of the estuary, $42 \%$ in the mesohaline part of the estuary, $34 \%$ in the polyhaline zone of the estuary, down to $24 \%$ in the Pertuis coastal zone (Fig. 5, bottom panel). Nonetheless, as seasonal nomads spend their life in the estuary, residents and seasonal nomads could be gathered into a group of estuary users. Then, the proportion of estuary users is quite stable in the different compartments of the estuary, with $53 \%$ in the upper part of the estuary, $59 \%$ in the mesohaline zone and $55 \%$ in the polyhaline zone of the estuary. Concurrently, the proportion of downstream nomads in- 
creases from $11 \%$ in the upper part of the estuary to $37 \%$ in the mesohaline part of the estuary, reaching a maximum of $45 \%$ in the polyhaline zone. Their proportion decreases again to $28 \%$ in the Pertuis coastal zone. This same trend was observed for seasonal nomads, with a maximum of $21 \%$ in the polyhaline zone of the estuary.

\section{'Allochthonous' fish}

Allochthonous fish were those eels which had a lifehistory pattern inconsistent with their site of capture, such as riverine residents collected in the estuary or estuarine eels collected in the Pertuis area. Since these fish came from neighbouring compartments, it is likely that they just moved to the habitat. The 23 riverine eels collected in the estuary very close to the limit of 0 psu salinity were mainly undifferentiated eels (15 undifferentiated, 8 females, 1 male), with a mean length of $337 \mathrm{~mm}$ (range 225 to $575 \mathrm{~mm}, 72.4 \%$ under $405 \mathrm{~mm}$ ). On the other hand, the 7 estuarine eels found in the Pertuis area were all females, with a mean length of $592 \mathrm{~mm}$ (range 385 to $720 \mathrm{~mm}, 85.7 \%$ above $525 \mathrm{~mm})$.

\section{Fish growth analysis}

Due to small sample size $(n=7)$, the upstream mode nomads were discarded from the analysis. A significant trend was observed in the growth rates of the different modes of habitat use (Fig. 6). The riverine residents tended to have lower growth rates (mean $\pm \mathrm{SD}$ : $52.6 \pm 10.92 \mathrm{~mm} \mathrm{yr}^{-1}$ ) than all other types of habitat use (60.91 $\pm 11.68 \mathrm{~mm} \mathrm{yr}^{-1}$; ANOVA, p < 0.001, Fig. 6). Despite a period of at least $1 \mathrm{yr}$ spent in freshwater for downstream nomads, there were no significant differences between their growth rate and the growth rate of the other eels that occupied brackish and marine habitats (ANOVA, p > 0.05).

'Downstream movement' nomad eels (the most abundant alternative to residence in the estuary) reached a larger total length (mean \pm SD: $524.35 \pm$ $18.03 \mathrm{~mm}$ ) than their resident counterparts (450.1 \pm $14.21 \mathrm{~mm}$; ANOVA, $\mathrm{p}<0.001)$. In correlation with length, downstream nomads became older (mean \pm SD: $8.5 \pm 0.35 \mathrm{yr})$ than estuarine resident fishes (7.34 \pm $0.27 \mathrm{yr}_{\text {; ANOVA, }}$ < 0.001). Analyse by sex could not detect any significant differences in lengths between downstream nomad females and estuarine resident females (ANOVA, $\mathrm{p}=0.06$ ) nor in ages (ANOVA $\mathrm{p}=$ 0.23). Differences between habitat-use patterns were not tested for undifferentiated or for male eels, due to small sample size.
The relationship between otolith radius and fish total length (Table 2) was significantly different for downstream nomads (Tukey-Kramer $0.001<\mathrm{p}<0.003$ ) and for resident fishes (marine, estuarine, or riverine), which together composed a homogenous group (Tukey-Kramer $0.43<\mathrm{p}<0.98$ ).

For the downstream nomads, migration from freshwater to the estuary mostly occurred during the second and third year of continental life (Fig. 7); $74 \%$ of the downstream nomads moved before Age 4+, and $91 \%$ moved before Age 5+. The distribution of the backcalculated length at the time of movement (Fig. 8) was also quite narrow, with $93 \%$ of the fish moving before reaching a length of $345 \mathrm{~mm}$. In addition, when comparing the size of nomads at the time of movement with the size of residents of the same age (GLM, adjustment for multiple comparison Tukey-Kramer), the length of the downstream nomads tended to be greater than that of their riverine counterparts when they moved in Age $2+(p<0.001)$, in Age $3+(p<0.001)$, in Age $4+(p<$ $0.002)$, as well as in Age $5+(p=0.04)$. In a similar manner, downstream nomads that moved in Age 2+ were larger than their estuarine resident counterparts of the same age $(p<0.001)$; the same pattern was observed for fish that moved at Age $3+(p<0.005)$ (Fig. 9).

\section{DISCUSSION}

\section{Proportions of patterns of habitat use}

Our study has shown that a $100 \%$ of the eels caught in freshwater habitats of the Gironde River basin were riverine residents, i.e. they settled and remained in the freshwater habitat. This result is in agreement with results obtained for other species and sites; $100 \%$ of

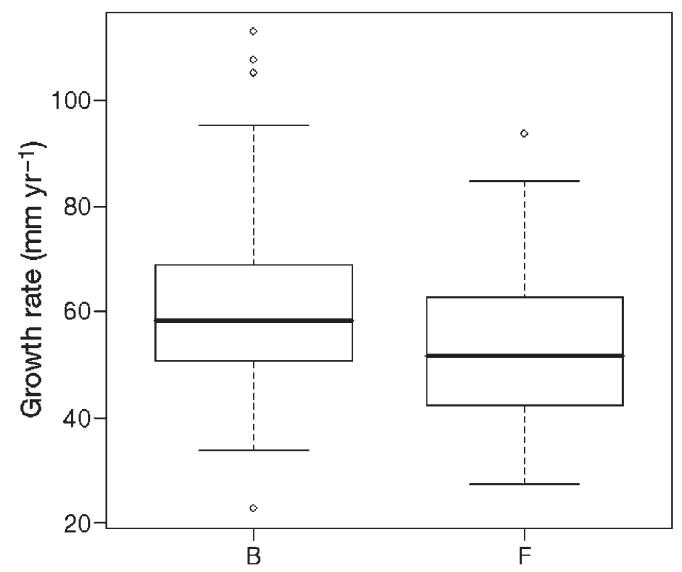

Fig. 6. Anguilla anguilla. Differences in fish growth rates for different habitat-use patterns. B: fish with a brackish habitat experience (estuarine and marine residents and nomads); F: freshwater residents 
Table 2. Anguilla anguilla. Generalised linear model estimates for the fish length to otolith length relationship

\begin{tabular}{|lcccrr|}
\hline & Parameter & Estimate & Error & $t$ & p \\
\hline Intercept & & 48.33 & 16.173 & 2.99 & 0.0031 \\
Otolith radius, $R_{\mathrm{c}}$ & & 289.76 & 8.90 & 32.57 & $<0.0001$ \\
Habitat use pattern & Residents (marine, estuarine, river) & -42.12 & 8.75 & -4.81 & $<0.0001$ \\
& 'Downstream nomads' & 0 & & & \\
\hline
\end{tabular}

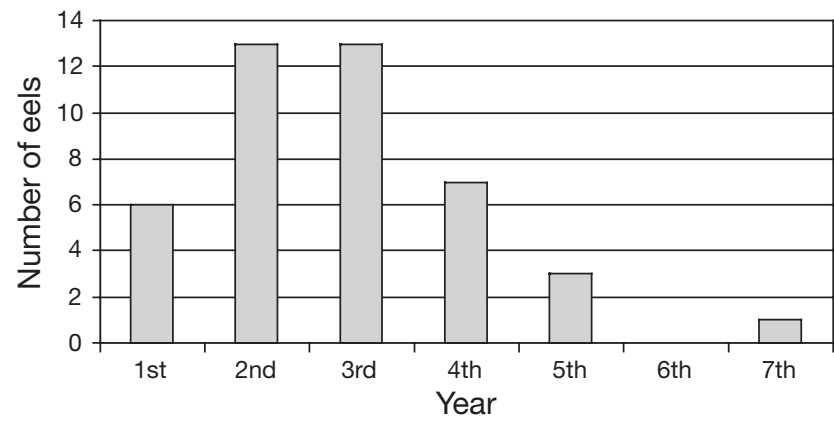

Fig. 7. Anguilla anguilla. Age class at habitat shift for eels that moved from freshwater habitat to the estuary (downstream nomads, Type 4)



Fig. 8. Anguilla anguilla. Frequency distribution of backcalculated total lengths at habitat shift for downstream mode nomads

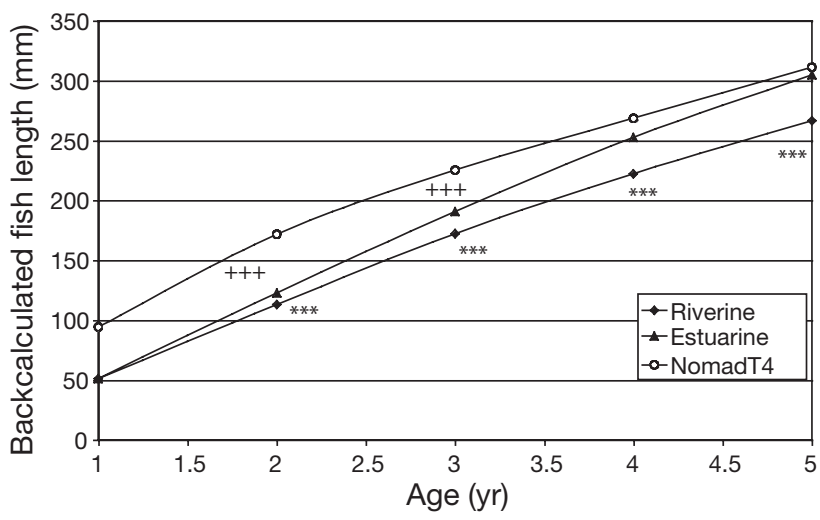

Fig. 9. Anguilla anguilla. Back-calculated sizes-at-age at habitat shift for downstream nomads and residents (riverine or estuarine). Significant differences $(p<0.005)$ between river residents and downstream nomads (***) and between estuary residents and downstream nomads (+++) are marked the freshwater American eels Anguilla rostrata were riverine residents $200 \mathrm{~km}$ away from the river mouth in the Hudson River basin (Morrison et al. 2003), 6 out of 7 A. japonica in Japan (Tsukamoto \& Arai 2001) and $100 \%$ of $A$. japonica in the Kaoping River, $40 \mathrm{~km}$ upstream from the river mouth (Tzeng et al. 2002). In the Gironde estuary nomad eels accounted for $41 \%$ of the sample, a large majority of which first had spent a few years in freshwater before moving downstream to the estuary. In comparison, the upstream behaviour was marginal (2\%). Our finding that downstream nomads represented from 11 to $45 \%$ of the sample collected in the upper estuary, the mesohaline zone, the polyhaline zone, or in the Pertuis coastal zone corroborated studies on $A$. japonica and A. rostrata. As reported by Tsukamoto \& Arai (2001) and T. Arai (pers. comm.), most of the eels classified as estuarine eels were eels that first settled in freshwater before moving to a higher salinity habitat (proportions were not specified). Similarly, $60 \%$ of the eels in the Koaping estuary first migrated into freshwater at a young age and then moved to the estuary at an age between 1 and $4 \mathrm{yr}$ (Tzeng et al. 2002), and $65 \%$ of the eels collected in the Hudson estuary (USA) were downstream nomads (Morrison et al. 2003). The differences in proportions of habitat use observed in different estuaries might be evidence of the plasticity of eel behaviour in its adaptation to an ecosystem. Thus, the relationship between proportions of habitat-use patterns and ecosystem parameters deserves further investigation.

In the Pertuis coastal zone, the proportion of nomads $(48 \%)$ was greater than the proportion of marine residents $(24 \%)$, suggesting that this ecosystem is very attractive to yellow eels. Proportions of habitat use differed drastically in the 2 coastal zones. The whole Arcachon Bay sample was composed of marine residents, as opposed to the $24 \%$ of marine residents in the Pertuis area. This difference may be explained by their relative connections with freshwater water masses. The Arcachon Bay is a large bay opened to the ocean, with little freshwater discharge, mainly by a sandy bottom river. In contrast, the Pertuis coastal zone is connected to several river basins and marshes (the Seudre, the Charente and the Sevre Niortaise Rivers), and, seasonally, the Gironde estuary panache also drains into the same coastal zone. 
The allochthonous riverine eels collected in the estuary very close to the limit of 0 psu salinity were mainly undifferentiated eels, with a mean length of $337 \mathrm{~mm}$, so that their movement could not be explained by silver eel migration. These fish might be downstream nomads on their way to the estuary. On the other hand, the 7 allochthonous estuarine eels found in the Pertuis area were all females, with mean length of $592 \mathrm{~mm}$ (range 385 to $720 \mathrm{~mm}$ ). These eels were potentially silver eels on their way to the spawning ground.

In the Gironde River basin, the group of fish that lived in a freshwater habitat (i.e. downstream nomads and riverine residents) constituted $50 \%$ of the overall sample. According to results obtained for Anguilla rostrata and A. japonica, considering the whole watershed, even a greater proportion of eels had experienced freshwater (Tzeng et al. 2002, Morrison et al. 2003). It seems that even though catadromy is not obligatory for eels, half of the fish captured along the watershed still experience freshwater at least for a short period of their life.

Our results showed that there was a gradient of residency behaviour in the Gironde River basin, with 100\% of residents in the river down to $24 \%$ in the Pertuis coastal zone. Concurrently, in the estuary, a gradient of a decreasing proportion of estuarine residents was observed. Downstream nomads were far more numerous than upstream nomads. This result seems to indicate that freshwater habitats are not attractive to yellow eels (i.e. $\mathrm{TL} \approx 300 \mathrm{~mm}$ ) compared to other zones of the watershed, as fewer fish migrate upstream. Instead, the Pertuis coastal zone and the polyhaline zone of the estuary attract, respectively, a proportion of 28 and $45 \%$ of the eels coming from a freshwater habitat. The polyhaline zone of the Gironde estuary and the Pertuis area are very productive ecosystems, they serve as nursery grounds for demersal species such as Dover sole, and marine species seasonally enter these areas as well (Lobry \& Rochard 2003). These results suggest a population dynamics whereby glass eels might not be able to settle in the estuary because of a very high level of competition, either with glass eel counterparts or with yellow eels. When eels achieve a certain size $(300 \mathrm{~mm})$, part of the freshwater population moves downstream to more favourable habitats, e.g. the estuary and the Pertuis area. More research is needed to test whether such a decreasing trend in residency can be found in other watersheds or is specific to the Gironde estuary.

\section{Growth patterns and mechanisms of tactic segregation}

Eels from brackish waters had a higher growth rate over their lifespan than eels from freshwater habitats in the Gironde. Growth performance does not seem as good in freshwater as in other more saline compartments of the watershed; this has also been shown for American eels (Morrison \& Secor 2003) and Baltic sea trout Salmo trutta (Limburg et al. 2001). Yet, this view of the eel population in the Gironde must be tempered, as results obtained from back-calculating lengths of estuarine residents, riverine residents and downstream nomads showed that the latter were already larger than riverine residents from early ages (Fig. 9). That is, the freshwater habitat held eels up to Age 5+ with 2 growth profiles: fast growth (downstream nomads) and slow growth (riverine eels). This bimodal distribution of sizes in freshwater areas has not yet been observed, which may be due to the fact that our sampling gear in freshwater tends to underrepresent small sizes. These results tend to suggest that, for the eel population of the Gironde watershed, habitats do not segregate growth patterns, as freshwater habitats hold both fast and slow growers. Moreover, these growth patterns are not modified by stays in freshwater, but are maintained, thus indicating a predetermined basis for these 2 growth performance patterns (Pujolar et al. 2005).

Comparisons of lengths-at-age of estuarine residents, riverine residents and downstream nomads have shown significant differences between Ages 1+ and 5+ (Fig. 9). Results from back-calculation show that, while riverine eels and downstream nomads maintain significantly distinct growth patterns between Ages 1+ and 5+, estuarine residents display an increasingly faster growth rate that results in sizes not significantly different from riverine residents (slow growers) at Age 1+ and not significantly different from downstream nomads at Age 5+ (fast growers). Interestingly, downstream nomads migrate at a size at which they are larger than their estuarine resident counterparts of the same age. At Ages 2+ and 3+, when most downstream nomads shift habitat, these are larger than estuarine residents and may take advantage of their larger size to colonise habitats occupied by residents. Therefore, our results suggest the existence of a temporal window, i.e. an age at which downstream migration is most advantageous. The distribution of ages at migration for downstream nomads supports this interpretation. As shown in Fig. 8, 74\% of downstream nomads migrate at Age 3+. Later than that, the advantage of size-at-age is lost against estuarine residents (Fig. 9) and fewer freshwater eels undertake the migration downstream. Tzeng et al. (2002) found that the eels in the Koaping estuary (Taiwan), that first migrated into freshwater at a young age, moved to the estuary between Ages 1+ and 4+, while Morrison et al. (2003) found that $78 \%$ of the downstream nomads moved before Age 5+.

In summary, this study revealed a pattern of habitat use at the scale of a river basin that allows freshwater 
eels to colonise estuarine and coastal habitats. In the estuary and in coastal habitats, precocious settlement of glass eel might be limited by intra-specific competition with eels of all sizes and inter-specific competition. The lower proportion of residents in the lower estuary and coastal habitats supports this hypothesis. In freshwater, results showed that 'slow growers' remained in the same habitat, while 'fast growers' moved to the estuary. The decision to leave the freshwater habitat for downstream areas is probably size dependent, as their migration is synchronised with a temporal window (Ages 2+ and 3+), when their size is greater than the size of estuary residents at the same age. Such a size-dependent temporal window has often been observed for salmonids (Jonsson \& Jonsson 1993, Thieriault \& Dodson 2003). This phenomenon allows eel settlement in highly productive, but highly competitive, habitats.

Acknowledgements. Research was supported through the PICASSO program (Programme d'Actions Intégrées FrancoEspagnol, Ministère des Affaires Etrangères, France) and the Programa de Acciones Integradas Hispano-Francesas (Ministerio de Educación y Ciencia, Spain). This work was facilitated by the DIADFISH network exchanges. Thanks are also due to Y. LeGatt and L. Beaulaton for assistance with statistical analyses. Three anonymous referees provided comments that improved the manuscript.

\section{LITERATURE CITED}

Anonymous (1998) Guidelines for the treatment of animals in behavioral research and teaching. Anim Behav 55: 251-257

Arai T, Kotake A, Lokman PM, Miller MJ, Tsukamoto K (2004) Evidence of different habitat use by New Zealand freshwater eels Anguilla australis and A. dieffenbachii, as revealed by otolith microchemistry. Mar Ecol Prog Ser 266:213-225

Castaing P (1981) Le transfert à l'océan des suspensions estuariennes, cas de la Gironde. Thèse de doctorat, Université de Bordeaux I

Daverat F, Elie P, Lahaye M (2004) Microchemistry contribution to a first approach to the diversity of life histories of eels from the lower part of the Gironde Garonne Dordogne watershed. Cybium 28:83-90

Daverat F, Tomas J, Lahaye M, Palmer M, Elie P (2005) Tracking continental habitat shifts of eels using otolith $\mathrm{Sr} / \mathrm{Ca}$ ratios: validation and application to the coastal, estuarine and riverine eels of the Gironde-Garonne-Dordogne watershed. Mar Freshw Res 56:619-627

Durif C, Dufour S, Elie P (2005) The silvering process of Anguilla anguilla: a new classification from the yellow resident to the silver migrating stage. J Fish Biol 66: 1025-1043

Edeline E, Dufour S, Briand C, Fatin D, Elie P (2004) Thyroid status related to migratory behavior in Anguilla anguilla glass eels. Mar Ecol Prog Ser 282:261-270

Francis RICC (1990) Back-calculation of fish length: a critical review. J. Fish Biol. 36:883-902

Graynoth E (1999) Improved otolith preparation, ageing and back-calculation techniques for New Zealand freshwater eels. Fish Res 42:137-146

Jessop BM, Shiao J-C, lizuka Y, Tzeng W-N (2002) Migratory behaviour and habitat use by American eels Anguilla rostrata as revealed by otolith microchemistry. Mar Ecol Prog Ser 233:217-229

Jonsson B, Jonsson N (1993) Partial migration: niche shift versus sexual maturation in fishes. Rev Fish Biol Fish 3:348-365

Kotake A, Okamura A, Yamada Y, Utoh T, Arai T, Miller MJ, Oka H, Tsukamoto K (2005) Seasonal variation in the migratory history of the Japanese eel Anguilla japonica in Mikawa Bay, Japan. Mar Ecol Prog Ser 293:213-225

Limburg KE, Landergren P, Westin L, Elfman M, Kristiansson $P$ (2001) Flexible modes of anadromy in Baltic sea trout: making the most of marginal spawning streams. J Fish Biol 59:682-695

Limburg KE, Svedang H, Elfman M, Kristiansson P (2003) Do stocked freshwater eels migrate? Evidence from the Baltic suggests 'yes'. In: Dixon DA (ed) Biology, management and protection of catadromous eels. Symposium 33, American Fisheries Society, Bethesda, MD, p 275-284

Lobry J, Rochard E (2003) The Gironde estuary: a European reference for fish population? In: River basin management-from experience to implementation. European Water Association, Hennef, p 63-77

McCullagh P, Nelder JA (1989) Generalized linear models. Chapman \& Hall, London

Morrison WE, Secor DH (2003) Demographic attributes of yellow-phase American eels (Anguilla rostrata) in the Hudson River estuary. Can J Fish Aquat Sci 60:1487-1501

Morrison WE, Secor DH, Piccoli PM (2003) Estuarine habitat use by Hudson River American eels as determined by otolith strontium:calcium ratios. In: Dixon DA (ed) Biology, management and protection of catadromous eels. Symposium 33, American Fisheries Society, Bethesda, MD, p $87-100$

Panfili J, Ximenes MC, Crivelli AJ (1994) Sources of variation in growth of the European eel (Anguilla anguilla) estimated from otoliths. Can J Fish Aquat Sci 51:506-515

Pujolar JM, Maes GE, Vancoillie C, Volckaert FAM (2005) Growth rate correlates to individual heterozygosity in the European eel, Anguilla anguilla L. Evolution 59: 189-199

Sottolichio A (1999) Modélisation de la dynamique des structures turbides (bouchon vaseux et crème de vase) dans l'estuaire de la Gironde. Thèse de doctorat, Université de Bordeaux I

Tesch FW (2003) The eel. Blackwell Publishing, Oxford

Thieriault V, Dodson JJ (2003) Body size and the adoption of a migratory tactic in brook char. J Fish Biol 63:1144-1159

Tsukamoto K, Arai T (2001) Facultative catadromy of the eel Anguilla japonica between freshwater and seawater habitats. Mar Ecol Prog Ser 220:265-276

Tzeng WN, Lin HR, Wang CH, Xu SN (2000a) Differences in size and growth rates of male and female migrating Japanese eels in Pearl River, China. J Fish Biol 57: 1245-1253

Tzeng WN, Wang CH, Wickstrom H, Reizenstein M (2000b) Occurrence of the semi-catadromous European eel Anguilla anguilla in the Baltic Sea. Mar Biol 137:93-98

Tzeng WN, Shiao JC, Iizuka Y (2002) Use of otolith Sr:Ca ratios to study the riverine migratory behaviors of Japanese eel Anguilla japonica. Mar Ecol Prog Ser 245:213-221

Tzeng WN, Iizuka Y, Shiao JC, Yamada Y, Oka H (2003) Identification and growth rates comparison of divergent migratory contingents of Japanese eel (Anguilla japonica). Aquaculture 216:77-86 